\title{
Rastin Swap Card (RSC): A Financial Instrument of Rastin Banking
}

\author{
Bijan Bidabad \\ B.A., M.Sc., Ph.D., Post-Doc. \\ Professor \\ Economics and Chief Islamic Banking Advisior \\ Bank Melli, Iran \\ E-mail:bijan@bidabad.com
}

\begin{abstract}
Rastin Swap Card is defined in Rastin Banking. This card is issued based on the Swap Contract in Rastin Banking or principle of sovereignty rights of contracts. In Rastin Swap Card there are two periods. In the first period card issuer lends money to the cardholder, and in the second period borrows money from card holder instead. At the first stage card issuer credits a certain amount of money for specific time duration to the card of cardholder and requests the cardholder to deposit the same amount for the same period at the end of the cited time duration (first maturity) in the issuer's deposit account. Card issuer and cardholder can agree for a combination of amount and duration for which the product of them (amount by the duration) be equal for both operations of lending money by the issuer and depositing by the cardholder.Rastin Swap Card (RSD) has no interest rate and is different from conventional debit and credit cards, but considering the ICT-based systems, RSD is being processed and managed through electronic banking systems. Rastin Swap Card can be issued in both local and foreign currencies. Bank receives a fee by offering Rastin Swap Card service.
\end{abstract}

Keywords: Rastin Swap Card, Rastin Swap Deposit, Rastin Swap Bond, Rastin Banking, Islamic Banking, Interest-Free Banking, Swap Contract

JEL: E43, E44, E52, E58, E62, E63

\section{Introduction}

Prohibition of Reba in divine religions, especially in Islam prevents using traditional financial instruments which has skepticism of involving Reba. Interest is involved in the calculation of the most of conventional banking instruments, and therefore, for facilitating Islamic financial activities, new financial instruments should be innovated in compliance with Sharia and in the direction of Reba prohibition.

In conventional banking credit card is one of the important financial instruments that are not applicable to Islamic banking. This paper introduces a new substitute for the credit card that is compliant with Sharia and is interest-free and can be used for financing purposes.

Rastin Swap Card is defined in Rastin Banking ${ }^{\mathrm{I}}$. This card is interest-free and is issued according to Swap Contract as defined in Rastin Banking Bill ${ }^{2}$ or based on the legal rule of the sovereignty of contracts. The card issuer for a specified amount and duration that is credited into the card, requests the cardholder to deposit the same amount of money for the same duration to the issuer's deposit account. Issuer and holder can agree to select a combination of amount and duration for which the product of them is equal for both credited and deposited (amounts and durations multiplications). The operational mechanism of Rastin Swap Card (RSC) is highly similar to Rastin Swap Bond which the latter is also issued in Rastin Banking.

\footnotetext{
${ }^{\mathrm{I}}$ Rastin Banking documents are accessible through: http://www.bidabad.com

2 Bijan Bidabad, Azarang Amirostovar, Saeed Abdollahi, Mahmoud Allahyarifard, Eskandar Pordel, Maryam Heidari, Alireza Shafiei, Mohammad Ali Pourbehrouz, Draft of Rastin Banking Bill, Bank Melli Iran, 2012. http://www.bidabad.com/doc/rastin-banking-bill.pdf
} 


\section{Bank Cards}

Two main groups of bank cards are used in banks as debit cards and credit cards. Both groups are processed and managed through electronic banking systems.

Debit Cards: are in the form of magnetic or smart cards and are processed online or offline. This type of cards is connected to a customer's account, and withdrawal over the account balance is not allowed. A debit card is also used for cash payment purchase through Point of Sale (POS) or via the internet and withdrawal from Automatic Teller Machines (ATM). Some banks, by offering this service levy bank fees and receive it from the customer. Once the debit card is credited, it can be used by the customer.

Credit Cards: are the cards that issuer (bank) gives to the customer and the customer without paying funds into his account can withdraw money for a certain amount as borrowing and or purchase through this card; and at maturity s/he is obliged to pay the fund back to the bank wholly or by installment. In case of non-fulfillment of obligation in the determined time period, the bank will pose an interest rate to the amount of fund for the delayed time, and customer and his guarantor are obliged to pay the principal and interest amounts. ${ }^{3}$

Companies, banks, financial and credit institutions finance the necessary resources for this activity to the bank or card issuer companies (such as Visa, MasterCard, and other companies with different names in monetary regions and different countries) and banks or cited companies shall manage them through their electronic payment systems. Credit limit granted to each customer depends on the customer's financial history and ability to repay the fund back to the bank.

This card is a usury financial instrument. Banks and intermediary companies in Islamic countries have tried to change the card characteristics and its operations to allege it as Islamic through use of formal Islamic contracts (e.g., Joalah and Murabaha contracts), but it is clear enough that interest is certainly not negligible in credit cards. Credit cards are often used in the context of people's consumption as consumer loans and are subject to the aggravated usury character. By this card, banks in most countries receive a high-interest rate from customers, and in cases, that the interest rate is compounded as well as the status of the Doubled Riba. Bank justifies the higher interest rates for this card because of its higher credit risk. This card is functionally compatible with the culture of consumerism. So that when the cardholder goes shopping centers with his family usually buys what his family or accompanies request, to satisfy them and falls actually in the trap of unwanted loan and interest. Subprime Credit Cards are issued with low credit and high interest and Secured Credit Cards are issued on the basis of guarantees or collateral.

Credit card holders are usually granted various facilities. For example, offering discounts or services such as travel, accident and health insurances and lack of interest on delayed payments for specific periods, etc. are among these facilities given to customers. Different types of banking credit exist in the banks. Loans, in general, are credit operations which are done in different ways and with different pledges. There is another type of credit operation that is served to the ranked customers' checking accounts. Using this type of credit, checking account holder can draw checks (or use his connected card to his checking account) more than his account balance. Customer is also charged by applying interest rate as other conventional loans. Thus it is also a usury loan and is not acceptable in Islamic banking.

\section{Rastin Swap Bonds (RSBs)}

As it was cited before, the operational mechanism of Rastin Swap Card (RSC) is highly similar to Rastin Swap Bond. Rastin Swap Bond is a financial paper that observes the right for the lender to borrow an equal amount to his lending from the borrower. The lender can sell his paper in the market at market price. In this bond, no interest rate is determined, but the market price of the bond is determined at each transaction in the market, and thus, the return of the bond is not fixed and not predetermined.

The financial structure of Rastin Swap Bonds is substantially different from conventional bonds and bills. In RSB, while there is no interest, the funds will be offered to the other party in the form of "debt equal to future loan", or "loan equal to future debt" with "time-drawing right". This also differentiates RSB from conventional bonds, as the latter are interest-bearing securities, whereas RSB is basically, non-interest-bearing financial certificate and with ownership claim. Similar to conventional debt securities, RSBs may be issued for a fixed period. The period variation is due to specific rules.

Generally, RSBs have two periods and two maturity dates. The first period is equal to $\mathrm{N}$ months from the selling time to the first maturity, and the second period is from the first maturity date $(\mathrm{N})$ until the payback date of funds $(\mathrm{kN}+\mathrm{N})$ or second maturity date. The first maturity is when the seller of papers is obliged to provide the loan equal to A dollars for $\mathrm{N}$ months, or

${ }^{3}$ Martin, Andrew (January 4, 2010). How Visa, Using Card Fees, Dominates a Market. New York Times.

CreditCards.com (2006). Prepaid debit card benefits and disadvantages. Creditcards.com. 
$\mathrm{A} / \mathrm{k}$ dollars for $\mathrm{kN}$ months to the buyer. Therefore, the first maturity occurs at the end of $\mathrm{N}$ months. The second maturity is the end of the contract when the seller will receive back his funds after $\mathrm{kN}+\mathrm{N}$ months after selling time.

Rastin Swap Bond is issued under certain conditions with a face value. Accordingly, by buying $\$ A$ bonds with a maturity of $\mathrm{N}$ months, the buyer will have the right to obtain $\$ A$ interest-free loan for a period of $\mathrm{N}$ months from the issuer of bonds. The buyer and seller agree on fixing combinations of $\$ A$ and $N$ months so that the buyer can choose smaller, equal or larger than one ratios from $\$ A$ in proportion with $N$ months in such a way that the result of the amount of money multiplied by time duration, be equal to $A \times N$. For example, buyer instead of A Dollars, can borrow A/ 2 Dollars for $2 \mathrm{~N}$ months at the $\mathrm{N}^{\text {th }}$ month, or $\$ A / 3$ for $3 \mathrm{~N}$ months at the $\mathrm{N}^{\text {th }}$ month. Where, in all cases, the result will be equal to $A \times N$. That is: $(\mathrm{A} / 2) \times(2 \mathrm{~N})=(\mathrm{A} / 3) \times(3 \mathrm{~N})=\mathrm{A} \times \mathrm{N}$ or generally speaking, instead of $\$ \mathrm{~A}$, we will receive $\$ \mathrm{~A} / \mathrm{k}$ for $\mathrm{k} \times \mathrm{N}$ months after the $\mathrm{N}$ months. The parameter $\mathrm{k}$ can be agreed mutually upon by the parties, or offered by the buyer. This procedure is depicted in figure I.

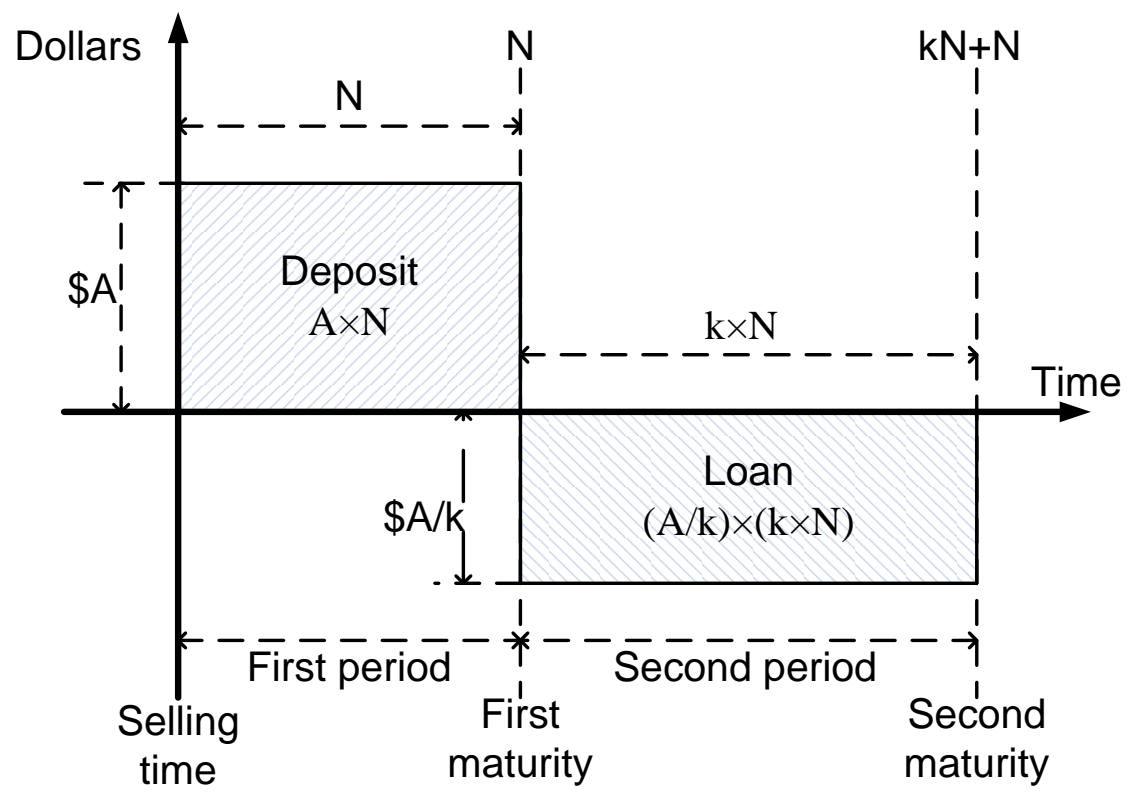

Figure I. Two-Phases Maturity of Rastin Swap Bonds

To facilitate Rastin Swap Bonds, the new Swap (Mubadala) Contract was defined in Rastin Banking. Swap (Mubadalah): is a contract in which one person (Mobadil) (swapper) undertakes to give the ownership of a certain asset (Badal)/(swapped asset) to the other party (Motabadit)/(one who receives the swapped asset) for a defined period; and the other person also undertakes to give the ownership of the same amount (Mobaddal)/(re-swapped) to the first person (Mobadil) for an equal period. Rastin Swap Bond is defined in Rastin Banking is based upon Mubadalah (swap) contract between Mobadil (swapper) and Motebadil (swappee) in which the durations and substances of swaps are equal for first and second swaps. Motebadil (swappee) issues the bond and owes to Mobadil (swapper) equal to the nominal value of the bond, and should pay this amount (badal)/(swapped) to Mobadil (swapper) at maturity. The issuer (Motebadil) is obliged to give the mobaadal (re-swapped) for the same amount and period as badal (swapped) to mobadil (swapper). He can choose a combination of amount and period that the multiplication of amount by the period of mobaddal (re-swapped) be equal to that of badal (swapped). At second maturity, mobadil (swapper) is committed to returning mobaddal (re-swapped) to motebadil (swappee). No interest rate is involved in these bonds, and they are of four kinds: Central Bank Rastin Swap Bond, Treasury Rastin Swap Bond, Bank Rastin Swap Bond, and Commercial Rastin Swap Bond. Regarding the fact that these bonds are not based upon participation and just indicate swapping of assets, is not covered by regulations of the Rastin PLS Base system, but uses its infrastructure such as organization and Rastin Certificate Market. $^{5}$

\footnotetext{
${ }^{4}$ Bijan Bidabad, Azarang Amirostovar, Saeed Abdollahi, Mahmoud Allahyarifard, Eskandar Pordel, Maryam Heidari, Alireza Shafiei, Mohammad Ali Pourbehrouz, Draft of Rastin Banking Executive Regulation, Bank Melli Iran, 2012.

http://www.bidabad.com/doc/rastin-banking-regulation.pdf

${ }^{5}$ Bijan Bidabad, Rastin Certificate Market (RCM), Complementary System of Rastin Banking, 2013.

http://www.bidabad.com/doc/rastin-bank-rcm-en.pdf
} 
Each type of RSBs can be transacted in the secondary market, but the transactions are permitted for different groups of seller and buyers (central bank, commercial banks, treasury, and public) for specific types of RSBs. RSBs pricing will be formed on a base of demand for and supply of money rather than a fixed interest rate for a fixed period. The interest rate of RSBs is zero, but the return is not fixed due to market bonds' prices changes. Thus, interest rate rigidity vanishes, and when the economy goes toward recession, price (return) of RSB becomes lower and reduces the cost of using money resources; and vice versa for the case of going toward prosperity. That is, RSBs have a built-in automatic adjustment mechanism, which stabilizes the economy. In other word, we can say that RSBs prices will be commensurate to the capital return of the real economy.

Similar to RSBs in domestic money, four kinds of foreign exchange nominated RSBs can also be issued. The only difference is that both loans of Rastin Foreign Exchange Swap Bonds should be in one unique currency; except for the Central Bank Rastin Foreign Exchange Swap Bonds that can be in two different currencies for the first and second periods. In neither cases, especially when one foreign exchange is used for the first period, and another foreign exchange is used in the other period, no skepticism of usury exists.

The monetary and fiscal effects, as well as their economic effects of issuing Rastin Swap Bonds have been discussed in different papers. $^{6}$

\section{Rastin Swap Deposit (RSD)}

Rastin Swap Deposit (RSD) is a kind of banking deposit account which is opened in Rastin Bank. Bank undertakes the commitment that for the same amount of money and the same time duration that depositor deposits his money in his RSD account, to lend money as a loan to the depositor. With the opening of this type of deposit account, the depositor is entitled to receive an interest-free loan from the bank up to the same amount of money and the same time duration that (depositor) had deposited in his bank account before, and at the end, the depositor returns the money back to the bank. ${ }^{7}$

\section{Rastin Swap Card (RSC)}

Rastin Swap Card (RSC) is a kind of bank card which is issued in Rastin Banking. Rastin Swap Card (RSC) is highly similar to Rastin Swap Bond as mentioned above. The main difference is that, unlike the Swap Bonds that depositing is done at first and then loan occurs; in Rastin Swap Card (RSC) loan is firstly occurred and then depositing will be. The distinction is cleared as by comparing figures I and 2 .

Customer (buyer/holder) requests the card issuer to issue the card with respect to a certain amount of money for certain time duration to be credited into the card. After then, for this service, the cardholder is obliged to deposit the same amount for the same duration in the bank's account, or a combination of amount and duration can be agreed based upon the multiplication of amount and duration of the money the bank lent customer through the card be equivalent to the money and duration that customer will deposit in the bank. At the first maturity, the cardholder returns the money back to the bank and deposits an amount equivalent to the amount he had borrowed for the same duration in the bank's account. After reaching the second maturity, the bank will release the deposited money from his account and transfer it to a customer's account.

The customer is obliged to give the necessary guarantee or collateral to the bank to bring faith to fulfill his obligations. Type of pledge or guarantee is determined by the bank due to his understanding of the customer financial history and the credited amount to the card. At the second maturity, guarantee or collateral of the customer is released when the obligation is fulfilled.

6 See:

- Bijan Bidabad, Islamic Monetary Policy, 2013. http://www.bidabad.com/doc/islamic-monetary-policy-en.pdf

- Bidabad, Bijan, Mahmoud Allahyarifard. Usury-Free Bonds and Islamic Central Banking Monetary Instruments. 2010.

http://www.bidabad.com/doc/Islamic-banking-bond-en.pdf

- Bidabad, Bijan, Abul Hassan, Ben Ali Mohamed Sami, Mahmoud Allahyarifard. Interest-Free Bonds and Central Banking Monetary Instruments. International Journal of Economics and Finance. Vol. 3, no. 3, Aug 20I1, pp.234-24I.

http://www.ccsenet.org/journal/index.php/ijef/article/download/II665/8300

- Bidabad, Bijan,Interest-Free Treasury Bonds (IFTB), 20I I. http://www.bidabad.com/doc/interest-free-t-bond-en.pdf http://www.bidabad.com/doc/iftb-en.pptx

- Bidabad, Bijan, Interest-Free Treasury Bonds (IFTB), Islamic Finance and Legal Clarifications, 201 I. http://www.bidabad.com/doc/interest-free-t-bond-feqhi-en.pdf

- Bidabad, Bijan, Abul Hassan, Ben Ali Mohamed Sami, Mahmoud Allahyarifard. Interest-Free Bonds Financial Innovation, A Monetary Instrument for Economy at Crisis. Journal of Economic Cooperation and Development (JECD). 32, I, 201 I, 55-70.

http://www.sesric.org/jecd/jecd_articles/ARTIOI0220I-2.pdf

${ }^{7}$ Bijan Bidabad, Rastin Swap Deposit, 2015, http://www.bidabad.com/doc/rsd-paper-en.pdf 
Rastin Swap Card is contracted based upon Mubadalah (swap) contract between Mobadil (swapper) and Motebadil (swappee) in which the durations and substances of swaps are equal for first and second swaps. Mobadil (swapper) is the card issuer and is creditor from Motebadil equal to the nominal value of the card, and Motebadil (customer) should pay this amount (badal) (swapped) to Mobadil (swapper/card issuer) at first maturity. The customer (Motebadil) is obliged to give the mobaadal (reswapped) for the same amount and period of badal to mobadil. He can choose a combination of amount and duration that the multiplication of amount by the duration of mobaddal (re-swapped) be equal to that of badal (swapped). At second maturity, motebadil (customer) is committed to returning mobaddal (re-swapped) to mobadil (card issuer). ${ }^{8}$ No interest rate is involved in this card. They can be in domestic money or foreign exchange currencies. The durations of swapped and re-swapped and interregnum duration are determined when the contract is signed. End of the Badal duration is called Badal (first) maturity, and the end of Mobaddal duration is called Mobaddal (second) maturity. Interregnum duration in Rastin Swap Card is the time interval between Badalmaturity and the start of Mobaddal duration.

In case of nonfulfillment of obligations at first maturity, Mobadil (card issuer) after receiving Badal can hold the Mobaddal beside himself in such a way that the multiplication of Badal duration by the amount of Badal is equal to the same multiplication for the sum of Mobaddal duration plus delayed duration by Mobaddal amount.

Rastin Swap Card can be both issued in foreign currencies as well as local currency. In this connection, there is no significant difference between the two above cards issued in local and foreign currencies except that the nominal amounts of both stages of the card could be foreign exchange. In any case, the currency type of Baddal and Mobaddal should be the same. If the card is issued for the case of different types of currencies for Badal and Mobaddal, there would be no Riba skepticism in the transaction yet. But to ascertain the case both sides of the contracts commit that at the first maturity, rate of currency exchange be applied to convert Badal in first currency into Mobaddal in the second currency.

Bank or card issuer receives a service fee for offering this service to customers. Regarding the fact that this card is not based upon participation and just swaps the money, it is not covered by regulation of the Rastin PLS Base system ${ }^{9}$ but uses its infrastructure and organization. ${ }^{10}$

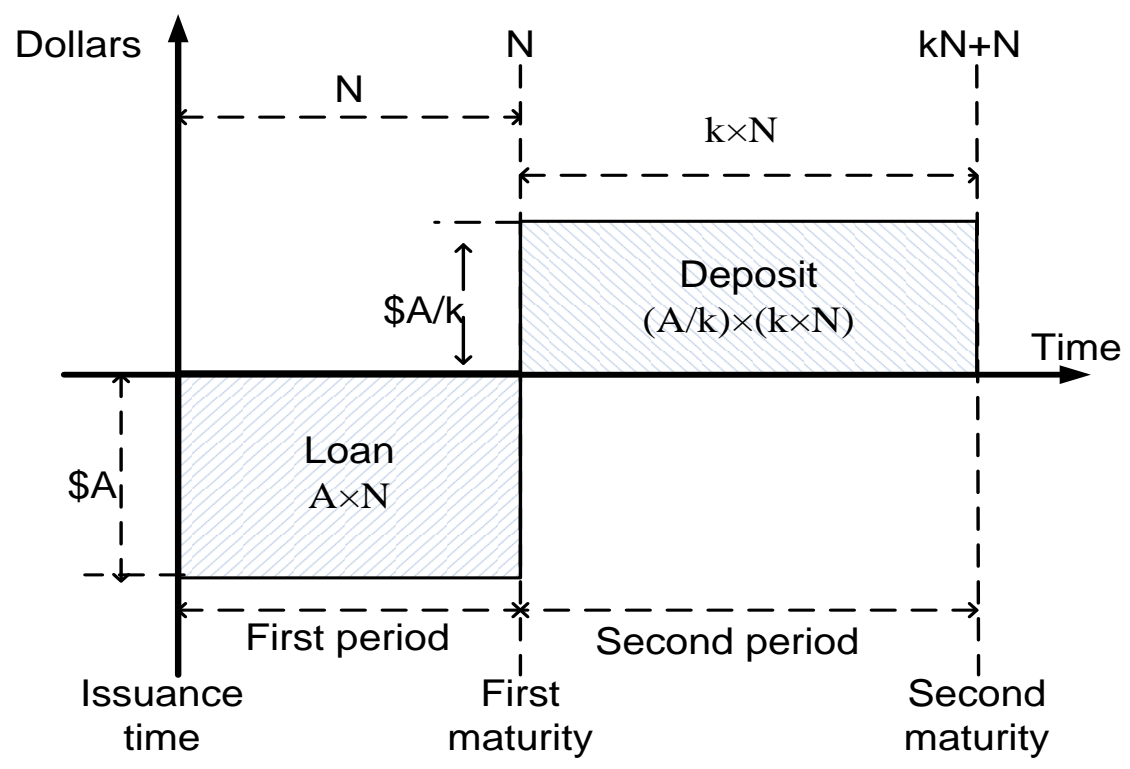

Figure 2. Two-Phases Maturity of Rastin Swap Card

\footnotetext{
${ }^{8}$ Bijan Bidabad, Azarang Amirostovar, Saeed Abdollahi, Mahmoud Allahyarifard, Eskandar Pordel, Maryam Heidari, Alireza Shafiei, Mohammad Ali Pourbehrouz, Draft of Rastin Banking Executive Regulation, Bank Melli Iran, 2012.

http://www.bidabad.com/doc/rastin-banking-regulation.pdf

${ }_{9}^{9}$ Bijan Bidabad, Rastin Profit and Loss Sharing (PLS) Base System. Journal of Islamic Economics, Banking and Finance, pp. 32-57, Vol. 9 No. 4, Oct - Dec 2013.

http://ibtra.com/pdf/journal/v9_n4_article2.pdf

http://www.bidabad.com/doc/pls-base-en.pdf

${ }^{10}$ Bijan Bidabad, M. Safarzadeh and J. Aghabeigi, Organization of Profit and Loss Sharing (PLS) Banking in Bank Melli Iran. Bank Meli Iran, 20I I. http://www.bidabad.com/doc/PLS-organization.pdf
} 


\section{Sharia Allowances of Rastin Swap Card (RSC)}

Essentially, usury occurs in loans, and loans have two different kinds of consumption and investment loans. Investment loans result in profit/loss, and the loan itself is not for spending or consumption. Consumption loans are used for everyday life spending. ${ }^{.1}$ Sharia prohibition reasoning mostly concern consumption loans ${ }^{12}$.

"Transaction usury" is defined as transacting a measurable commodity/money with a surplus amount of the same commodity/money. Because of the excessive amount paid to the other party; this transaction involves usury, and is prohibited by Sharia. In "transaction usury", transacting equal amount along a period is not considered, but transacting with an extra amount is at the focus of attention. That is why Rastin Swap Card does not enter into the domain of "usury transaction; because its financial activity is not based upon transaction of extra amount, just equal amounts are bartered along two periods, and creditor obtains no surplus.

In "loan usury", a person lends (money or commodity) and receives it back with a surplus. In "loan usury", the surplus has not necessarily the same type or quality of the original commodity and includes any kind of surplus. Rastin Swap Card is not "loan usury" as well.

The spiritual reference of the verses 278-28I of Surah of Baqarah: "Your capitals will be yours, you won't suppress and will not be suppressed" approves the correctness of Rastin Swap Card ${ }^{13}$. This is because according to "your capitals will be yours", the principal loan will be returned to the lender, and in order to prevent doing any oppression, or being oppressed "you won't suppress and will not be suppressed", he will receive loan in an equal amount of what he had lent, which exactly complies the meaning of this verse.

\section{Legal Institution for Rastin Swap Card (RSC)}

Many of monetary and banking activities are regarded as new subjects in civil laws of many countries. Civil laws have not reckoned all transaction contracts and has just mentioned some evidence such as pure transaction contract, conditional transaction, forward deal, spot transaction, over the counter transaction, future (Salaff) and prepaid (Salam) purchase, irrevocable transaction, optional transaction, valuable metals transaction, unauthorized transaction and etc. Therefore, we will not be wrong if we consider RSC with its similarities to "transaction contract", while the possessory right is suspended during the period of contract.

Promissory contracts seem to be a solution for the legal framework for RSC. New "counter-loaned contract" in which two parties decide to deposit a specific asset with the other party for a same period, and also "counter-trust contract" can be defined in this regard. But, revocability of promissory contracts creates difficulty for application of "counter-loaned contract" and "counter-trust contract" and "donation against loan contract" with zero donations in applying for Rastin Swap Card ${ }^{14}$. In this connection, the application of "time-barter contract" is not meaningless. Accordingly, we define "time-barter contract" in which a party lends an asset to the other party, in order to receive the same asset from him in future without considering that one of them is assets and the other is its price. If we consider the loan contract without surplus, "time-loan contract" might also be defined. We may define "time-loan contract" according to which each party loans the possession of his own specific asset to the other and the other party will loan back the similar asset with similar quality and amount to him at maturity, and if he cannot render the same asset, he should pay its spot price at the time of contracting. In all of these frames, one deposits some asset with the other person, and he will pay back the same amount at the maturity without any surplus or privilege.

However, as a conclusion, Rastin Swap Card is contracted based upon Mubadalah (swap) contract. But without legislation of this contract as law, the Rastin Swap Card can be contracted based upon the principle of sovereignty of contracts that is well known in law.

\footnotetext{
${ }^{I I}$ - Bidabad, Bijan, Economic-juristic analysis of usury in consumption and investment loans and contemporary jurisprudence shortages in exploring legislator commandments. Proceeding of the $2^{\text {nd }}$ International Islamic Banking Conference. Monash University of Malaysia. 9-IO September 2004. Reprinted in: National Interest, Journal of the Center for Strategic Research, Vol. 2, No. I, winter 2006, pp. 72-90. Tehran, Iran. http://www.bidabad.com/doc/reba-en.pdf

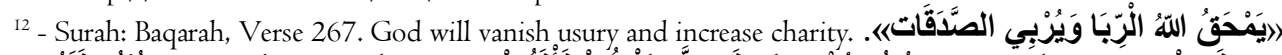

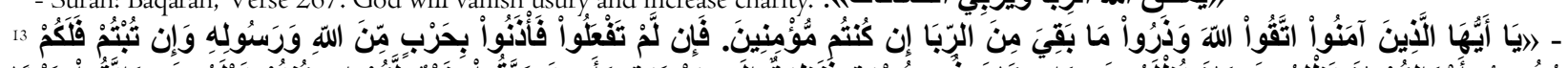

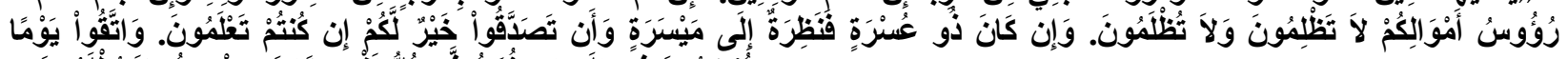

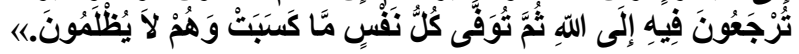

O! Believers, care about God; leave what is left through usury. But if you don't, you should know that you are fighting against God and his messengers; and if you repent, your capitals will be yours. You won't suppress and will not be suppressed. If your debtors are poor, give them time until they obtain money; and if you bestow, it will be much better for you if you understand. Beware of the day you return to God, and then whatever obtained, will be returned to everybody; and they will not be suppressed.

${ }^{\text {I4 }}$ - Bidabad, Bijan, Legal analysis of Interest-Free Bonds http://www.bidabad.com/doc/legal-analysis-of-non-usury-bonds.pdf 


\section{References}

Bidabad, Bijan (2019) Interest-Free Treasury Bonds (IFTB), Islamic Finance and Legal Clarifications, 20II. International Journal of Islamic Business \& Management, 3(I), 2I-29, 2019. http://www.bidabad.com/doc/interest-free-t-bond-feqhi-en.pdf https://www.cribfb.com/journal/index.php/ijibm/article/view/258/353

Bidabad, Bijan,Interest-Free Treasury Bonds (IFTB), $201 \mathrm{I}$. http://www.bidabad.com/doc/interest-free-t-bond-en.pdf http://www.bidabad.com/doc/iftb-en.pptx

Bidabad, Bijan, Abul Hassan, Ben Ali Mohamed Sami, Mahmoud Allahyarifard. Interest-Free Bonds Financial Innovation, A Monetary Instrument for Economy at Crisis. Journal of Economic Cooperation and Development (JECD). 32, I, 20I I, 55-70.

http://www.sesric.org/jecd/jecd_articles/ARTIOI0220I-2.pdf

Bidabad, Bijan; Mahmoud Allahyarifard (2010). Usury-Free Bonds and Islamic Central Banking Monetary Instruments. http://www.bidabad.com/doc/Islamic-banking-bond-en.pdf

Bidabad, Bijan; Azarang Amirostovar, Saeed Abdollahi, Mahmoud Allahyarifard, Eskandar Pordel, Maryam Heidari, Alireza Shafiei, Mohammad Ali Pourbehrouz, Draft of Rastin Banking Bill, Bank Melli Iran, 2012. http://www.bidabad.com/doc/rastin-banking-bill.pdf

Bidabad, Bijan; Azarang Amirostovar, Saeed Abdollahi, Mahmoud Allahyarifard, Eskandar Pordel, Maryam Heidari, Alireza Shafiei, Mohammad Ali Pourbehrouz, Draft of Rastin Banking Executive Regulation, Bank Melli Iran, 2012. http://www.bidabad.com/doc/rastin-banking-regulation.pdf

Bidabad, Bijan, Rastin Certificate Market (RCM), Complementary System of Rastin Banking, 20I3. International Journal of Islamic Business \& Management, 3(I), 35-43, 2019. https://www.cribfb.com/journal/index.php/ijibm/article/view/260 http://www.bidabad.com/doc/rastin-bank-rcm-en.pdf

Bidabad, Bijan; Islamic Monetary Policy, 2013. http://www.bidabad.com/doc/islamic-monetary-policy-en.pdf

Bidabad, Bijan; Abul Hassan, Ben Ali Mohamed Sami, Mahmoud Allahyarifard. Interest-Free Bonds and Central Banking Monetary Instruments. International Journal of Economics and Finance. Vol. 3, no. 3, August 201 I, pp. $234-241$. http://www.ccsenet.org/journal/index.php/ijef/article/download/I I665/8300

Bidabad, Bijan; Abul Hassan, Ben Ali Mohamed Sami, Mahmoud Allahyarifard. Interest-Free Bonds Financial Innovation, A Monetary Instrument for Economy at Crisis. Journal of Economic Cooperation and Development (JECD). 32, I, 20I I, $55-70$. http://www.sesric.org/jecd/jecd_articles/ARTIOI0220I-2.pdf

Bidabad, Bijan; Rastin Swap Deposit, 2015. http://www.bidabad.com/doc/rsd-paper-en.pdf

Bidabad, Bijan; Rastin Profit and Loss Sharing (PLS) Base System. Journal of Islamic Economics, Banking and Finance, pp. 3257, Vol. 9 No. 4, Oct-Dec 2013. http://ibtra.com/pdf/journal/v9_n4_article2.pdf http://www.bidabad.com/doc/pls-base-en.pdf

Bidabad, Bijan; M. Safarzadeh, and J. Aghabeigi, Organization of Profit and Loss Sharing (PLS) Banking in Bank Melli Iran. Bank Meli Iran, 201 I. http://www.bidabad.com/doc/PLS-organization.pdf

Bidabad, Bijan, Economic-juristic analysis of usury in consumption and investment loans and contemporary jurisprudence shortages in exploring legislator commandments. Proceeding of the $2^{\text {nd }}$ International Islamic Banking Conference. The Monash University of Malaysia. 9-I0 September 2004. Reprinted in: National Interest, Journal of the Center for Strategic Research, Vol. 2, No. I, winter 2006, pp. 72-90. Tehran, Iran. http://www.bidabad.com/doc/reba-en.pdf 
Bidabad, Bijan, Legal analysis of Interest-Free Bonds http://www.bidabad.com/doc/legal-analysis-of-non-usury-bonds.pdf

Bidabad, Bijan. (2014). New Operational Islamic Banking System, Volume One, Theoretical Foundations, LAP Lambert Academic Publishing, OmniScriptum GmbH \& Co. KG, ISBN: 978-3-659-54463-7.

Bidabad, Bijan. (20I4). New Operational Islamic Banking System, Volume Two, Applicational Issues, LAP Lambert Academic Publishing, OmniScriptum GmbH \& Co. KG, ISBN: 978-3-659-552I0-6.

Bidabad, Bijan (2018), General Regulatory Framework in Rastin Profit and Loss Sharing Banking (Part I-Operational Context). Journal of Business and Finance in Emerging Markets, JBFEM, [S.1.], v. I, n. I, p. I I-26, May. ISSN 2580-5568. https://doi.org/I0.32770/jbfem.volI I I-26

http://www.bidabad.com/doc/rastin-regulatory-en-I.pdf

Bidabad, Bijan (2018), General Regulatory Framework in Rastin Profit and Loss Sharing Banking (Part II-Legal Groundwork). Journal of Business and Finance in Emerging Markets, JBFEM, JBFEM, [S.1.], v. I, n. 2, p. I09-I26, Nov. ISSN 25805568.

https://doi.org/I0.32770/jbfem.volII09-126

http://www.bidabad.com/doc/rastin-regulatory-en-II.pdf

Bidabad, Bijan (2019), General Regulatory Framework in Rastin Profit and Loss Sharing Banking (Part III-Auxiliary Provisions). Journal of Business and Finance in Emerging Markets, JBFEM, May, Vol 2, No. I, pp. 5I-65. ISSN 25805568.

https://doi.org/I0.32770/jbfem.vol25I-66

http://www.bidabad.com/doc/rastin-regulatory-en-III.pdf

CreditCards.com (2006). Prepaid debit card benefits and disadvantages. Creditcards.com.

Martin, Andrew (January 4, 2010). How Visa, Using Card Fees, Dominates a Market. New York Times.

Rastin Banking documents are accessible through http://www.bidabad.com

\section{Copyrights}

Copyright for this article is retained by the author(s), with first publication rights granted to the journal. This is an open-access article distributed under the terms and conditions of the Creative Commons Attribution license (http://creativecommons.org/licenses/by/4.0/). 